\title{
Evaluation of conductive cooling of lactating dairy cows under controlled environmental conditions
}

\author{
X. A. Ortiz, ${ }^{*}$ J. F. Smith, ${ }^{* 1}$ F. Rojano,† C. Y. Choi,ł J. Bruer,§ T. Steele,§ N. Schuring,\# J. Allen,II \\ and R. J. Collier*2 \\ *School of Animal and Comparative Biomedical Sciences, and \\ †Department of Agricultural and Biosystems Engineering, University of Arizona, Tucson 85719 \\ ‡Department of Biological Systems Engineering, University of Wisconsin-Madison, Madison 53706 \\ §Conco Technology Inc., Chandler, AZ 85226 \\ \#GEA Farm Technologies, Naperville, IL 60563 \\ IIDepartment of Agricultural Sciences, Northwest Missouri State University, Maryville 64468
}

\begin{abstract}
Cooling systems used to reduce heat stress in dairy operations require high energy, water usage, or both. Steady increases in electricity costs and reduction of water availability and an increase in water usage regulations require evaluation of passive cooling systems to cool cows and reduce use of water and electricity. A study was conducted to evaluate the use of heat exchangers buried $25 \mathrm{~cm}$ below the surface as components in a conductive system for cooling cows. Six cows were housed in environmentally controlled rooms with tiestall beds, which were equipped with a heat exchanger and filled with $25 \mathrm{~cm}$ of either sand or dried manure. Beds were connected to supply and return lines and individually controlled. Two beds (one per each kind of bedding material) constituted a control group (water off), and the other 4 (2 sand and 2 dried manure) used water at $7^{\circ} \mathrm{C}$ passing through the heat exchangers (water on). The experiment was divided in 2 periods of $40 \mathrm{~d}$, and each period involved 3 repetitions of 3 different climates (hot and dry, thermo neutral, and hot and humid). Each cow was randomly assigned to a different treatment after each repetition was over. Sand bedding remained cooler than dried manure bedding in all environments and at all levels of cooling (water on or off). Bed temperatures were lower and heat flux higher during the bed treatment with sand and water on. We also detected a reduction in core body temperatures, respiration rates, rectal temperatures, and skin temperatures of those cows during the sand and water on treatment. Feed intake and milk yield numerically increased during the bed treatment with sand and water on for all climates. No major changes were observed
\end{abstract}

Received July 8, 2014.

Accepted November 10, 2014.

${ }^{1}$ Deceased.

${ }^{2}$ Corresponding author: rcollier@ag.arizona.edu in the lying time of cows or the composition of the milk produced. We conclude that use of heat exchangers is a viable adjunct to systems that employ fans, misters, and evaporative cooling methods to mitigate effects of heat stress on dairy cows. Sand was superior to dried manure as a bedding material in combination with heat exchangers.

Key words: conductive cooling, heat stress, dairy cow

\section{INTRODUCTION}

A combination of genetics with good management techniques has steadily increased milk production per cow to the current level of $9,980 \mathrm{~kg} / \mathrm{cow}$ (USDA, 2013). However, this increase in milk production also increased the amount of metabolic heat produced by a dairy cow (Kadzere et al., 2002). Higher metabolic heat production requires additional measures for cooling a cow during times of thermal stress (Collier et al., 2006).

Standard heat-abatement techniques used in the dairy industry rely on water and fans to either cool down the environment in which the cows are housed or apply water to increase the rate of evaporation that typically occurs from the skin of a cow.

Electricity usage of these cooling systems ranges between 0.71 and $1.76 \mathrm{~kW} / \mathrm{h}$ depending on the intensity of the heat-abatement model used (St-Pierre et al., 2003). According to Harner et al. (2013), the amount of water needed for heat abatement in a dairy farm ranges between 56 and $75 \mathrm{~L} /$ cow per day during the heatstress season $(120 \mathrm{~d})$. However, water consumption and availability pose major problems for today's dairy operators. The depletion of clean water supplies and the increasing cost of water and electricity in the United States are becoming limiting issues in some states. Additionally, regulations concerning water availability for livestock production will likely be more restrictive in future years. New passive methods for cooling livestock need to be investigated to maintain high levels of milk 
production while increasing the efficiency of water and electricity consumption.

Conductive cooling is 1 of 4 routes of heat exchange available to cows to transfer the metabolic heat they produce to the environment. It involves the flow of heat from the skin of a cow down a thermal gradient to a surface that has a lower temperature. The effectiveness of conductive cooling is directly related to the size of the temperature gradient between the 2 bodies, the thermophysical properties of the media, and the size of the contact area between these 2 bodies (SchmidtNielsen, 1964). Conductive temperature exchange has also been described as a product of the proportional relationship between the conductivity of materials and their bulk density (Esmay, 1969).

Little research has been done evaluating the effectiveness of conductive cooling on dairy cows. Only $20 \%$ of the surface area of a cow is available for exchanging heat via conduction. Bastian et al. (2003) analyzed the use of cooled waterbeds as a method for increasing the size of the thermal gradient and for increasing the heat flow between the cows and their beds. Results of this study demonstrated an increase in the heat flux between a water-filled mattress and cows when the water temperature decreased and the thermal conductivity of the bodies increased. To evaluate the ability of a conductive cooling system to alleviate heat stress when placed underneath the bedding material of a cow, Mondaca et al. (2013) developed a comprehensive model capable of simulating the conjugate heat and mass transfer of a dairy cow. The model predicts the amount of heat that will leave the animal as a result of conductive cooling, and it demonstrates the potential of heat exchangers buried below the bedding surface as an alternative way to increase the heat flow from cows to the environment. Accordingly, the present experiment was designed to measure the effectiveness of heat exchange through bedding material as a conductive cooling system.

In commercial dairy farms the bedding material is selected based on its economic feasibility, the physical comfort it will provide, and how well it can maintain the cleanliness and health of the udder. When choosing a bedding material, however, not many producers take into consideration the thermal comfort of the cow. Cummins (1998) stated that the bedding material on a dairy farm should be part of any heat-abatement strategy. Cummings reported lower temperatures in limestone $\left(25.9^{\circ} \mathrm{C}\right)$ and sand $\left(26.9^{\circ} \mathrm{C}\right)$, compared with wood shavings $\left(28.6^{\circ} \mathrm{C}\right)$, at $25 \mathrm{~mm}$ below the surface. A more recent computational and experimental study showed that sand bedding had higher heat flux with cows when compared with straw and mattresses filled with rubber granules (Radoń et al., 2014). Two of the most frequently used bedding materials are sand and dried manure. In recent years producers have been trying to shift from using sand to dried manure because of cost and availability. Previous research had shown that sand and dried manure are both suitable as bedding materials (Cook et al., 2004; van Gastelen et al., 2011; Husfeldt et al., 2012).

The objective of this experiment was to evaluate the effects of these 2 types of bedding and their interaction with a bed heat-exchanger cooling system [cooling system + sand, cooling system + dry manure, and control (no water flowing through the heat exchanger in either bedding material)] operating during 3 different types of climates (thermo-neutral zone, hot and dry, and hot and humid).

\section{MATERIALS AND METHODS}

This experiment was conducted in the environmental rooms at the William J. Parker Agricultural Research Complex at the University of Arizona. To conduct the experiment, 6 multiparous Holstein dairy cows producing an average of $36.1 \pm 5.5 \mathrm{~kg} / \mathrm{d}$ of milk and $315 \pm$ 20 DIM were purchased from a commercial dairy. The cows were housed in tie stalls and were fed and milked twice daily (0600 and $1800 \mathrm{~h}$ ). The ration fed to the cows is shown in Table 1.

The trial was divided into 2 periods of $40 \mathrm{~d}$ each, and each period consisted of 3 repetitions of 3 different climates (hot and dry, thermo neutral, and hot and humid). At the beginning of each period an acclimation phase of $7 \mathrm{~d}$ was established. Each repetition consisted of $9 \mathrm{~d}$ ( $3 \mathrm{~d}$ per climate), and after each repetition,

Table 1. Ingredients and chemical composition of $\operatorname{diet}^{1}$

\begin{tabular}{lc}
\hline Item & Value \\
\hline Ingredient, \% of DM & \\
Alfalfa hay & 65.0 \\
Corn (steam flaked) & 22.1 \\
Whole cottonseed & 7.28 \\
Distillers grains & 2.58 \\
Supplement RS-1299 ${ }^{2}$ & 2.04 \\
MAXXER & 0.96 \\
Chemical analysis & \\
CP, \% & 17 \\
NDF, \% & 26.4 \\
ADF, \% & 20.2 \\
Fat, \% & 4.9 \\
DM, \% & 53.0 \\
NE, Mcal/kg of DM & 1.76 \\
\hline
\end{tabular}

${ }^{1}$ Diet DM averaged $53 \%$ by weight of DM, and water added was $47 \%$ by weight.

${ }^{2}$ The supplement contained $1.14 \%$ fat, $10.42 \%$ Ca, $4.49 \%$ P, $3.80 \%$ $\mathrm{Mg}, 0.49 \% \mathrm{~S}, 0.19 \% \mathrm{~K}, 15.83 \% \mathrm{Na}, 7.52 \% \mathrm{Cl}, 2,029.06 \mathrm{mg} / \mathrm{kg}$ of $\mathrm{Zn}$, $1,991.82 \mathrm{mg} / \mathrm{kg}$ of $\mathrm{Mn}, 974.24 \mathrm{mg} / \mathrm{kg}$ of $\mathrm{Fe}, 583.45 \mathrm{mg} / \mathrm{kg}$ of Cu, 67.86 $\mathrm{mg} / \mathrm{kg}$ of Co, $12.28 \mathrm{mg} / \mathrm{kg}$ of Se, $6.81 \mathrm{mg} / \mathrm{kg}$ of $\mathrm{Mo}, 43.68 \mathrm{mg} / \mathrm{kg}$ of $\mathrm{I}, 304.9 \mathrm{IU} / \mathrm{g}$ of vitamin A, $30.2 \mathrm{IU} / \mathrm{g}$ of vitamin $\mathrm{D}$, and $1.0 \mathrm{IU} / \mathrm{g}$ of vitamin E (Tarome Inc., Eloy, AZ).

${ }^{3}$ Calcium salts of palm oil (Tarome Inc.). 
a period of $3 \mathrm{~d}$ was given to cows to reset cows to thermo-neutral conditions (Figure 1). Three repetitions were done to reduce variability in the results of the experiment. Three circadian environmental conditions were programed in the computer that controlled the environmental room. For the hot and dry environment a minimum temperature of $24^{\circ} \mathrm{C}$, a maximum temperature of $41^{\circ} \mathrm{C}$, and an average temperature of $34.41^{\circ} \mathrm{C}$ was set. The relative humidity $(\mathbf{R H})$ was set at a minimum of $18 \%$, a maximum of $25 \%$, and an average of $22.5 \%$. The temperature-humidity index (THI) was set at a minimum of 67 , a maximum of 86 , and an average of 78 . The thermo-neutral environment was set at a minimum temperature of $8^{\circ} \mathrm{C}$, a maximum temperature of $23^{\circ} \mathrm{C}$, and an average temperature of $16.83^{\circ} \mathrm{C}$. The $\mathrm{RH}$ was set at a minimum of $18 \%$, a maximum of $25 \%$, and an average of $22.5 \%$. The THI was set at a minimum of 45 , a maximum of 66 , and an average of 56 . The hot and humid environment was set at a minimum temperature of $19^{\circ} \mathrm{C}$, a maximum temperature of $34^{\circ} \mathrm{C}$, and an average temperature of $27.97^{\circ} \mathrm{C}$. The $\mathrm{RH}$ was set at a minimum of $65 \%$, a maximum of $90 \%$, and an average of $80 \%$. The THI was set at a minimum of 67 , a maximum of 86 , and an average of 78 .

Three RH and temperature sensors (HOBO U23 Pro v2, Onset Computer Corporation, Cape Cod, MA) were placed in different locations in the environmental room to record data at 15-min intervals (Figure 2).

\section{Stall Preparation}

A total of 6 stalls in one environmental room were modified for this experiment $(2.13 \times 1.21 \mathrm{~m})$. First, cement blocks were used to raise the stall to create a deeper bedding capacity, and the depth of the stalls was increased an equivalent $40 \mathrm{~cm}$. Styrofoam insulation $(2.54 \mathrm{~cm}$ thick, $\mathrm{R}$-value $=5)$ was used to line the interior wall of the cement block of the stalls to insulate each bed. Three centimeters of bedding material was placed between the bottom of the bed and the heat exchanger. A single heat exchangers (Bruer and Steele, 2011) was then placed on the base of each bed, along with water supply and return lines (Figure 3). Three beds per bedding material were randomly assigned, by coin flip, either sand or dried manure (DRM) as the bedding material (Figure 2). On top of the heat exchanger, $10 \mathrm{~cm}$ of bedding material was first added. Temperature and moisture sensors (6470 Temperature and 6440 Soil moisture probe, Davis Instrument Corp., Hayward, CA) and heat flux sensors (HSF-4, Omega Engineering Inc., Stamford, CT) were placed on top of the bedding material according to the grid shown in Figure 4. An additional $15 \mathrm{~cm}$ of bedding material was then added on top, for a total of $25 \mathrm{~cm}$ of bedding material between the cow and the heat exchanger. Using a series of computational simulations, Mondaca et al. (2013) was able to show that the effectiveness of the heat exchanger is directly affected by the thickness of the layer of bedding material under which the exchanger is placed; that is, conductive heat loss decreased at a steady rate as the placement depth increased. The $25-\mathrm{cm}$ bedding depth used in the present study was chosen because it was judged the minimum required to protect the heat exchanger, prevent lameness, and provide sufficient physical comfort. After placement, the bedding mate-

40 Days

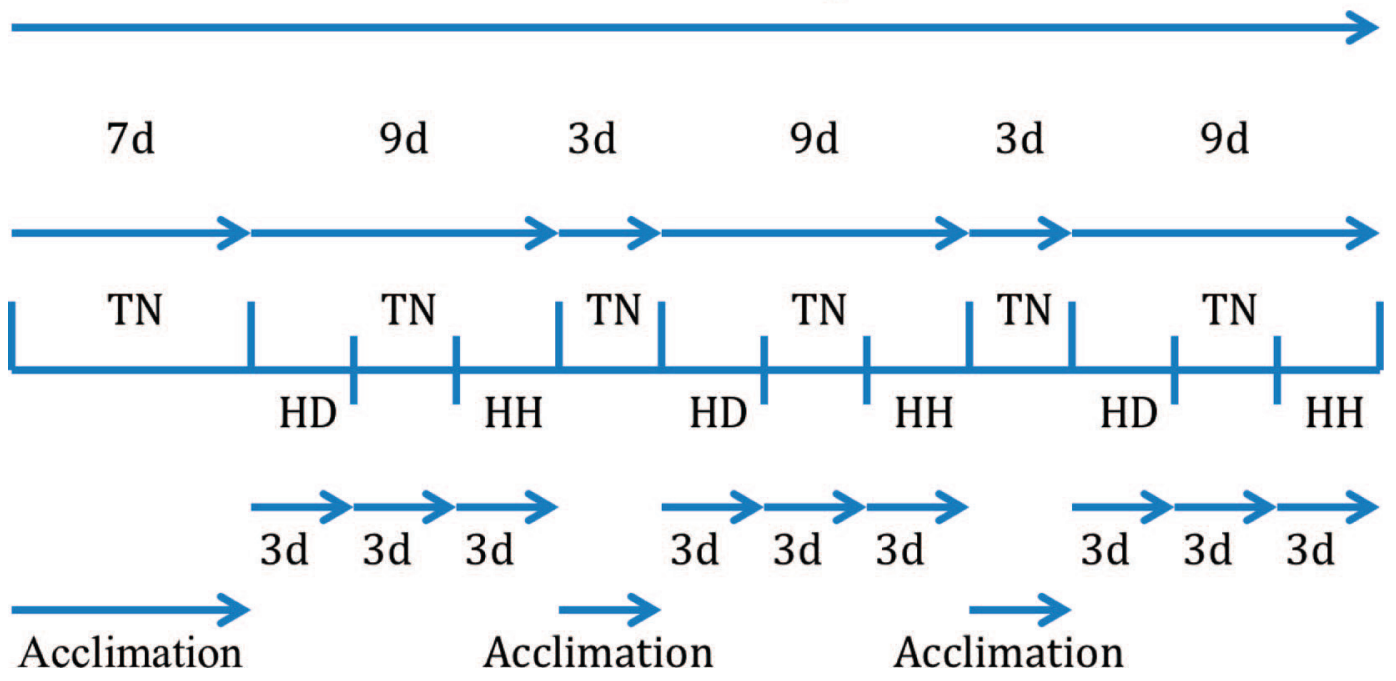

Figure 1. Sequence of climates and acclimation phases for each of 2 periods of the study. TN $=$ thermo neutral, HD $=$ hot and dry, and HH $=$ hot and humid. Color version available online. 


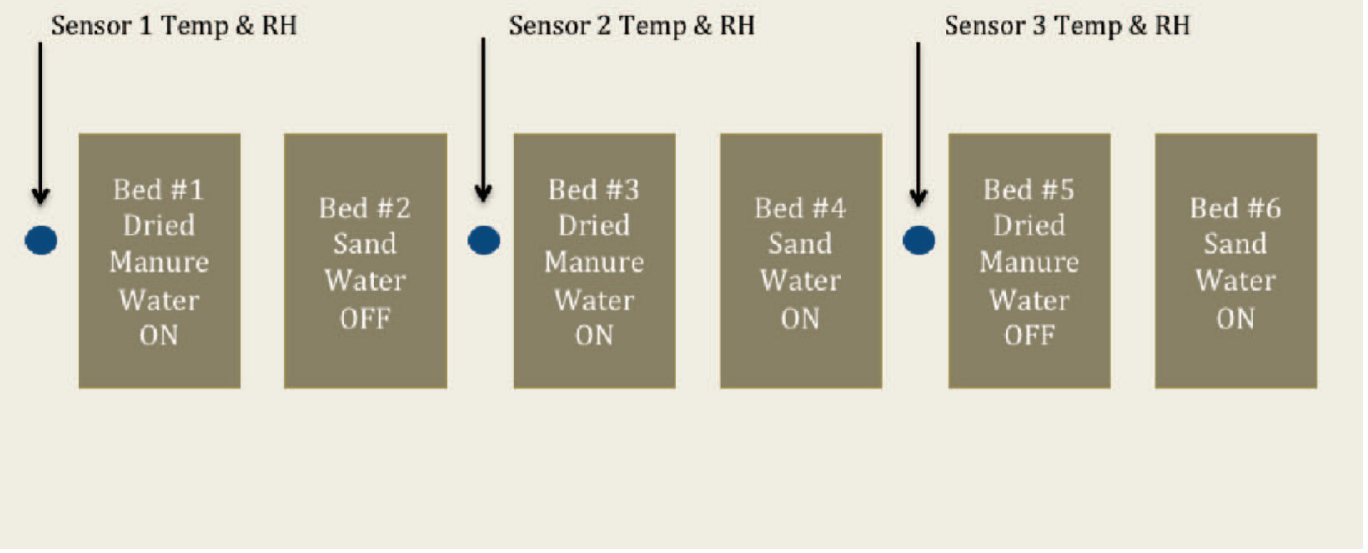

Figure 2. Description of bed treatments, location, bedding type, and sensor placement within the environmental room. Temp $=$ temperature, $\mathrm{RH}=$ relative humidity. Color version available online.

rial was compacted in all the beds to eliminate air pockets.

After the stalls were completed, 2 stalls, 1 for each bedding material, were designated as the control beds (water off) Figure 2. For the other 4 beds of each bedding-material type, the water was on at a rate of $3.78 \mathrm{~L} / \mathrm{min}$ on the fourth day of the acclimation phase. The designation of the control beds (water off) was done randomly, by coin flip. The water circulated through the heat exchangers at a temperature of $7^{\circ} \mathrm{C}$, and once it left the heat exchangers, this water was recirculated through a water-cooling system to bring the temperature back to $7^{\circ} \mathrm{C}$. To sample and record the temperature values every $5 \mathrm{~min}, 2$ thermometer data loggers were installed in the water line, one at the supply line and one at the return line.
The 6 cows were randomly assigned to the different treatments in a $2 \times 2$ factorial design with 2 types of bedding material (sand or DRM) and the heat exchanger with the water either on or off. No other cooling system was used in this experiment besides the heat exchangers to cool down the cows.

After each repetition (9 d), the cows were moved to a handling area for exercise to prevent leg and hoof problems. While the cows were out of their stalls, the beds were cleaned, and any soiled bedding material was replaced. Once the beds were prepared, each cow was randomly assigned to a different treatment.

Feed delivered and refused was recorded daily for each cow. For milk composition analysis (by Arizona DHIA), milk samples were taken from each cow during each a.m. milking. The California Mastitis Test was

\section{Feed Box End of Room}

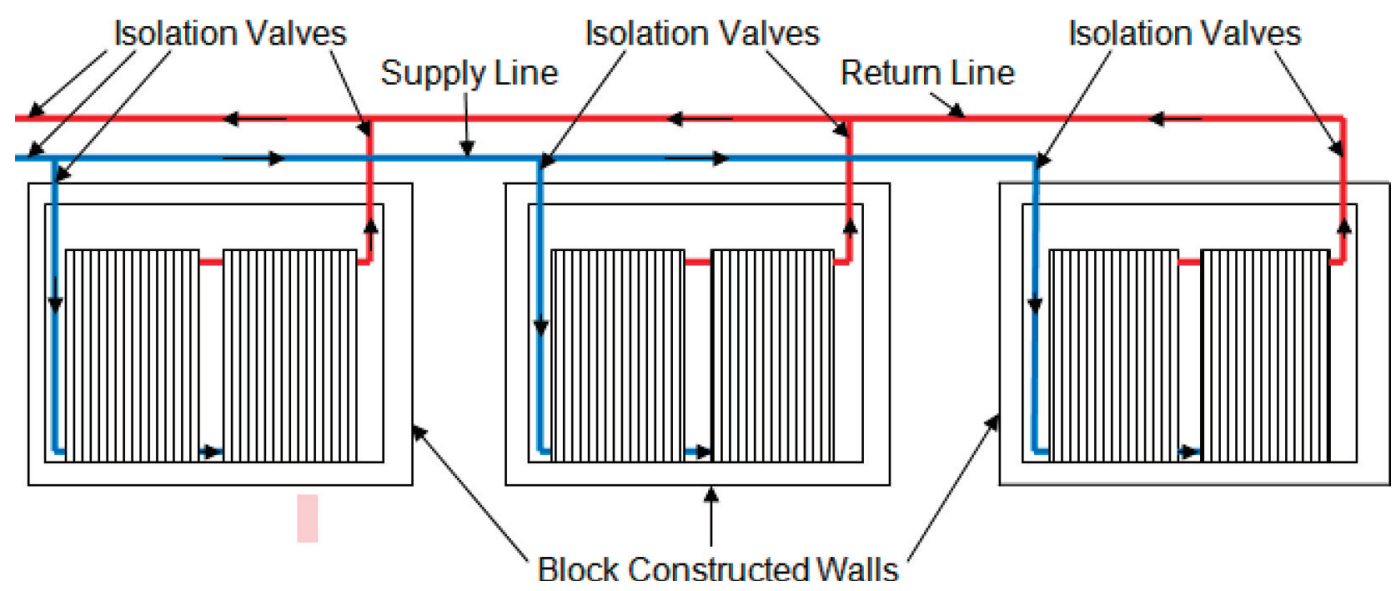

Figure 3. Water supply and return through heat exchangers in stalls of the environmental room. Color version available online. 


\section{Anterior view}

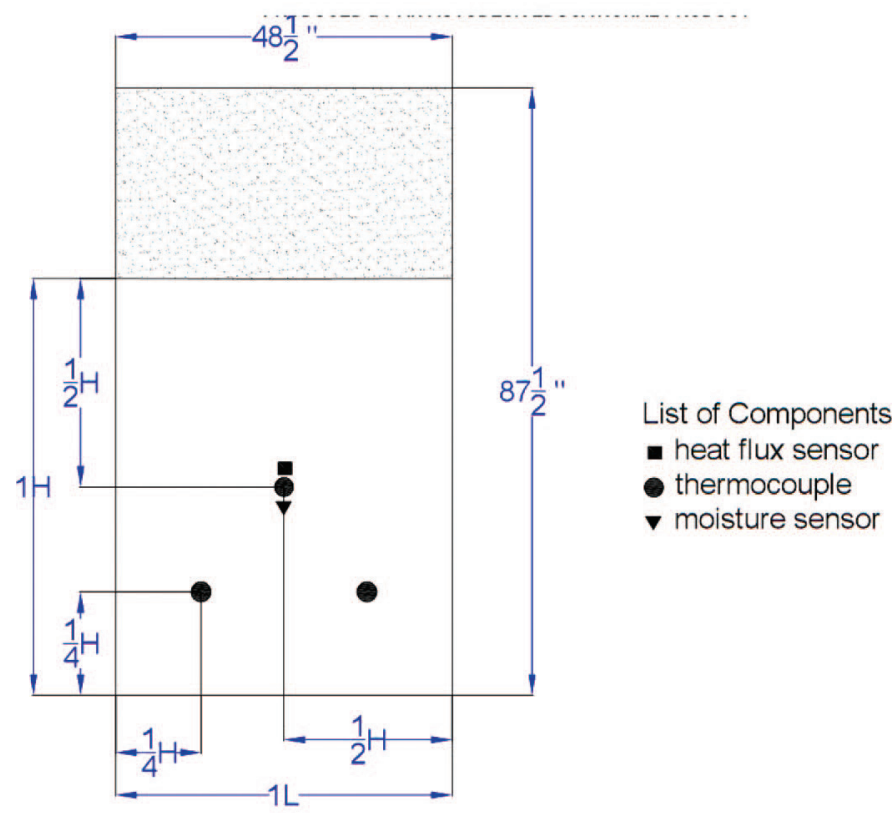

\section{Posterior view}

Figure 4. Placement of sensors in each stall. $\mathrm{H}=$ height, $\mathrm{L}=$ length. Color version available online.

conducted every day during the a.m. milking to test for presence of mastitis. Soiled bedding material was removed 3 times per day and replaced with fresh material to prevent the accumulation of moisture due to water from the water trough, feces, and urine.

Core body temperature (CBT) measurements were taken using intravaginal data logger devices (HOBO U12, Onset Computer Corporation). The data loggers remained inside the cows for $6 \mathrm{~d}$ per repetition, measuring the CBT of the cows at 5-min intervals. Physiological measurements such as respiration rates, skin temperature, and rectal temperature were recorded for each cow 4 times per day (1000, 1200, 1400, and $1600 \mathrm{~h})$. Respiration rates were taken by counting flank movements for $15 \mathrm{~s}$. Rectal temperature data were collected with the GLA M525/550 thermometer (GLA Agricultural Electronics., San Luis Obispo, CA). Skin temperature was measured in the rump, tail, head, and shoulder area of each cow. Skin temperatures were taken with an infrared thermometer (Raynger, Raytek MX, Fluke Corporation, Everett, WA).

Because of the importance of lying time during a conductive cooling trial, position sensors (HOBO Pendant G, Onset Computer Corporation) were placed on the rear right leg of each cow. These sensors were placed on the fourth day after the cows entered the environmental room, and they remained attached to the cows during the entire duration of the study. Position sensors were programmed to record data at 15-min intervals.

An infrared thermometer (Raynger, Raytek MX, Fluke Corporation) was used to collect bed surface temperatures every day from the head and the tail areas of the bed.

The moisture content of each bed was recorded at the end of the study. Three bedding samples per bed were taken at different depths (surface, middle, and above the heat exchanger). The samples were taken at $0.61 \mathrm{~m}$ inside the sidewall and $1.5 \mathrm{~m}$ inside the tail end of the stall. Samples were collected in plastic containers covered with aluminum foil and then transferred to glass vessels for weighing calculations. Bedding samples were placed in a drying oven at $170^{\circ} \mathrm{C}$ for $69 \mathrm{~h}$ and then weighed again to calculate moisture-content values.

All animals in this study were handled and treated according to the Institutional Animal Care and Use Committee of the University of Arizona.

\section{Statistical Analysis}

Data generated in this experiment were analyzed with a mixed model of SAS (Version 9.3, SAS Institute Inc., Cary, NC). Vaginal temperature, respiration rates, skin temperature, bed temperature, bed surface temperature, heat flux, feed intake, milk yield, milk composition, resting time, and SCC were analyzed according to the following model:

$$
Y_{i j}=\mu+T_{i}+C_{j}+A_{k}+H_{l}+T_{i} C_{j}+T_{i} C_{j} H_{l}+e_{i j},
$$

where $Y_{i j}=$ individual data point, $\mu=$ overall mean, $T_{i}$ = fixed effect of bed treatment ( $i=1$ to 4$), C_{j}=$ fixed climate effect ( $j=1$ to 3$), A_{k}=$ random effect of cow $(k$ $=1$ to 6$), H_{l}=$ fixed effect of time $(l=1$ to 24$), e_{i j}=$ residual error. Treatment effects were tested by means of the PDIFF option and were declared significant at $P<0.05$.

\section{RESULTS}

Mean 24-h ambient temperature, $\mathrm{RH}$, and THI for the different climates (hot and dry, thermo neutral, and hot and humid) tested in this experiment are illustrated in Figures 5, 6, and 7. Mean ambient conditions for the different climates were $34.01^{\circ} \mathrm{C}, 24.12 \% \mathrm{RH}$, and 78.66 THI for hot and dry; $18.5^{\circ} \mathrm{C}, 34.27 \% \mathrm{RH}$, and $62.73 \mathrm{THI}$ for thermo neutral; and $28.6^{\circ} \mathrm{C}, 62.91 \% \mathrm{RH}$, and 78.57 THI for hot and humid. Maximum ambient conditions for the different climates were $41.53^{\circ} \mathrm{C}, 31.47 \% \mathrm{RH}$, and $86 \mathrm{THI}$ for hot and dry; $28.67^{\circ} \mathrm{C}, 46.83 \% \mathrm{RH}$, and 73.10 THI for thermo neutral; and $34.45^{\circ} \mathrm{C}, 68.89 \% \mathrm{RH}$, and 


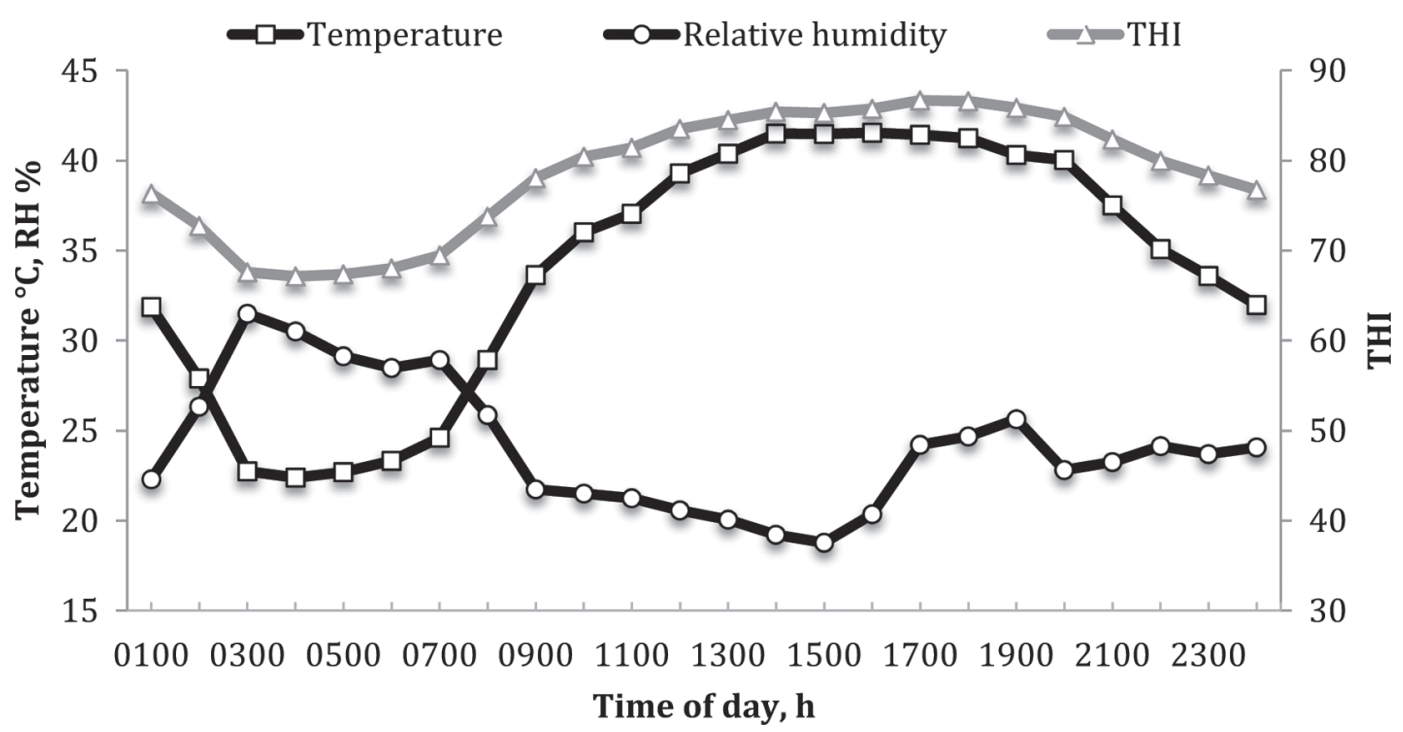

Figure 5. Average ambient temperature, relative humidity (RH), and temperature-humidity index (THI) by hour for the hot and dry environment.

86.74 THI for hot and humid. Minimum ambient conditions for the different climates were $22.38^{\circ} \mathrm{C}, 18.78 \%$ $\mathrm{RH}$, and $67 \mathrm{THI}$ for hot and dry; $13.22^{\circ} \mathrm{C}, 22.99 \% \mathrm{RH}$, and $56.70 \mathrm{THI}$ for thermo neutral; and $21.04^{\circ} \mathrm{C}, 45.24 \%$ $\mathrm{RH}$, and 67.59 THI for hot and humid.

Mean temperatures for each bed treatment at $10 \mathrm{~cm}$ above the heat exchanger and $15 \mathrm{~cm}$ below the surface are illustrated in Table 2 . The bed treatment with sand and water on maintained consistently lower $(P<0.05$, Table 2) temperatures compared with the other bed treatments in the 3 climates $\left(14.9,13.5\right.$, and $15.3^{\circ} \mathrm{C}$ for hot and dry, thermo neutral, and hot and humid, respectively). Table 2 shows the differences between the mean surface temperatures of bed treatments in their respective climate. Bed surface temperatures for the treatment with sand and water on were lower compared with the other bed treatments in heat-stress climates (24.4, 15.6, and $26.2^{\circ} \mathrm{C}$ for hot and dry, thermo neutral, and hot and humid, respectively).

As Table 2 shows, the heat exchanger lowered the bed temperature in both bedding materials (sand and DRM) in the 3 different climates; however, the temperature reduction was greater for sand $(P<0.05$, Table 2).

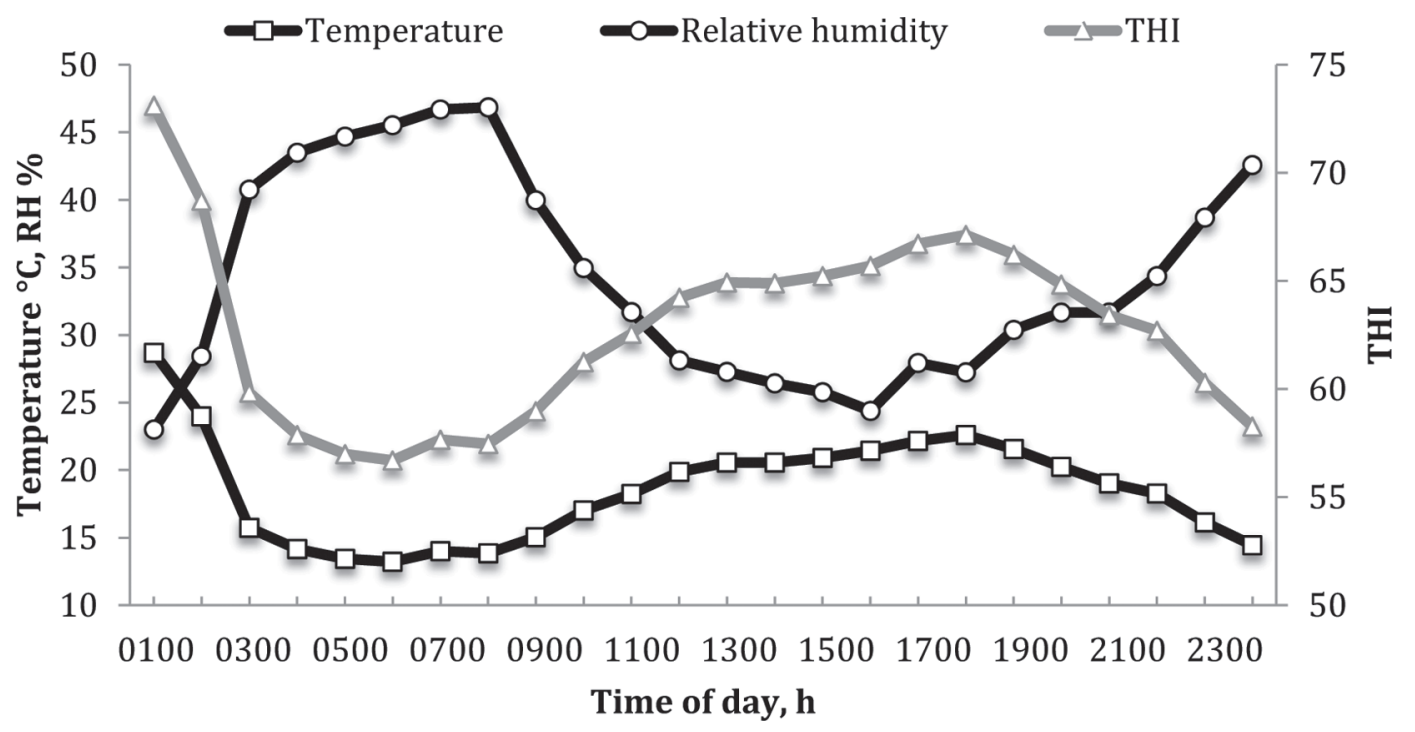

Figure 6. Average ambient temperature, relative humidity $(\mathrm{RH})$, and temperature-humidity index (THI) by hour for the thermo-neutral environment. 


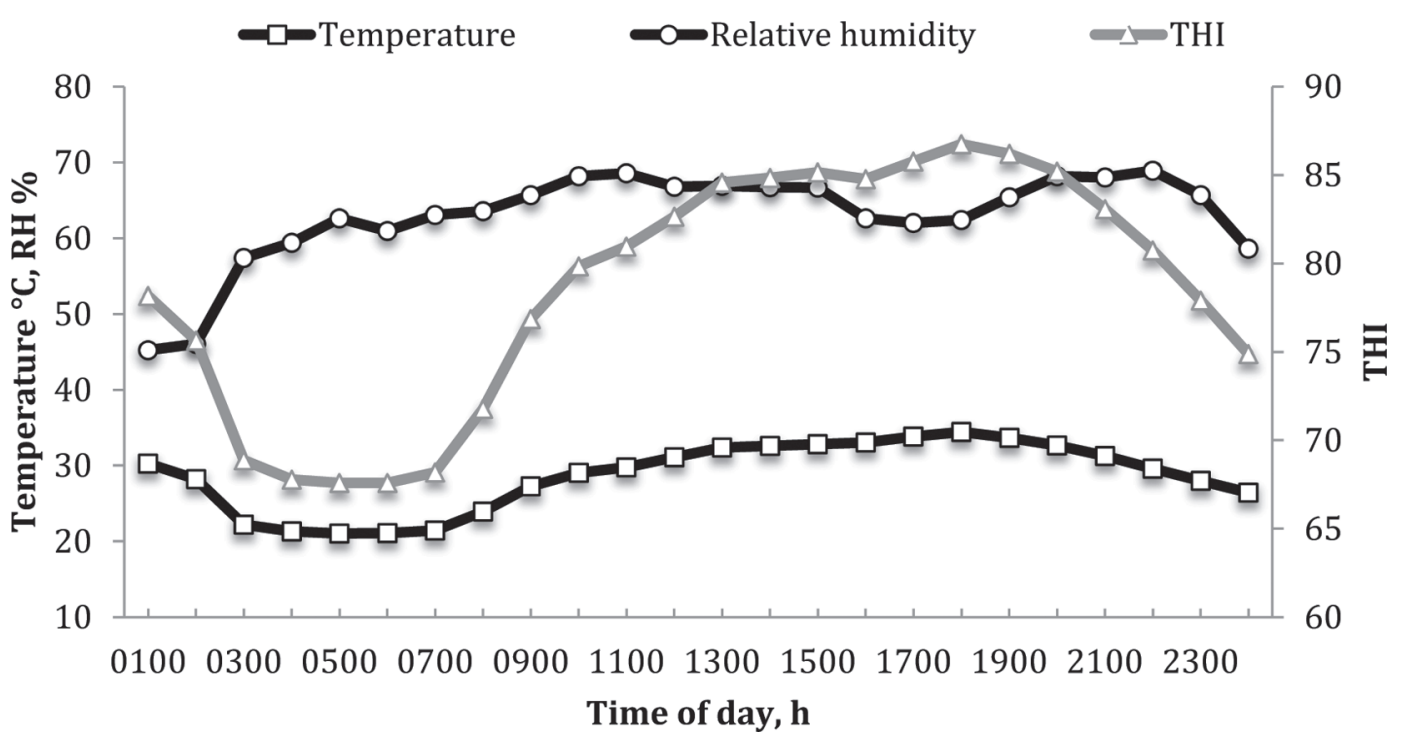

Figure 7. Average ambient temperature, relative humidity (RH), and temperature-humidity index (THI) by hour for the hot and humid environment.

The mean 24-h CBT of the cows in this experiment are shown in Table 3. Bed treatments differed, with the lowest CBT registered for the bed treatment with sand and water on in heat-stress climates (38.77 and $38.64^{\circ} \mathrm{C}$ for hot and dry and hot and humid, respectively, $P<0.05$, Table 3 ). The CBT of the cows on both bedding materials were reduced with the use of the heat exchanger in hot and dry and hot and humid environments.

The continuous CBT of the cows during the different bed treatments under the 3 environments are shown in Figure 8, 9, and 10. Treatment and time interacted in all the climates $(P<0.001$, Figure 8,9 , and 10$)$; however, the biggest difference between bed treatments was observed during the hot and dry and hot and humid climates $(P<0.001$, Figure 8 and 10). For the hot and dry climate, the biggest difference was observed at $1600 \mathrm{~h}$; temperatures at this hour were 39.47 and $39.88^{\circ} \mathrm{C}$ for sand and water on, and DRM and water off, respectively. For the hot and humid climate the biggest difference was observed at $1900 \mathrm{~h} \mathrm{(39.18}$ and $39.88^{\circ} \mathrm{C}$ for sand and water on, and DRM and water off, respectively).

Mean rectal temperatures are presented in Table 4 . Rectal temperatures were lowest in the bed treatments with sand and water on during heat-stress environ-

Table 2. Effect of bedding type and cooled water flow (on vs. off) on bed temperatures (surface and 25-cm depth) and heat flux between the heat exchanger and the cow

\begin{tabular}{|c|c|c|c|c|}
\hline Item & Bed treatment $^{1}$ & \multicolumn{3}{|c|}{ Measurement } \\
\hline \multicolumn{5}{|l|}{ Climate } \\
\hline \multirow[t]{3}{*}{ Hot and dry } & Sand and water on & $14.9^{\mathrm{a}}$ & $24.4^{\mathrm{a}}$ & $26.75^{\mathrm{a}}$ \\
\hline & Sand and water off & $26.6^{\mathrm{b}}$ & $26.0^{\mathrm{ab}}$ & $2.87^{\mathrm{b}}$ \\
\hline & DRM and water on & $21.4^{\mathrm{c}}$ & $25.4^{\mathrm{ab}}$ & $11.09^{\mathrm{c}}$ \\
\hline \multirow{3}{*}{ Thermo neutral } & Sand and water off & $25.6^{\mathrm{b}}$ & $16.9^{\mathrm{ab}}$ & $3.06^{\mathrm{b}}$ \\
\hline & DRM and water on & $19.9^{\mathrm{c}}$ & $16.0^{\mathrm{a}}$ & $9.21^{\mathrm{c}}$ \\
\hline & DRM and water off & $27.1^{\mathrm{d}}$ & $18.1^{\mathrm{b}}$ & $2.42^{\mathrm{b}}$ \\
\hline \multirow[t]{4}{*}{ Hot and humid } & Sand and water on & $15.3^{\mathrm{a}}$ & $26.2^{\mathrm{a}}$ & $28.63^{\mathrm{a}}$ \\
\hline & Sand and water off & $27.7^{\mathrm{b}}$ & $27.3^{\mathrm{ab}}$ & $3.40^{\mathrm{b}}$ \\
\hline & DRM and water on & $22.1^{\mathrm{c}}$ & $26.9^{\mathrm{ab}}$ & $7.25^{\mathrm{c}}$ \\
\hline & DRM and water off & $26.8^{\mathrm{d}}$ & $28.5^{\mathrm{b}}$ & $4.13^{\mathrm{b}}$ \\
\hline
\end{tabular}

${ }^{\mathrm{a}-\mathrm{d}}$ Means within each climate with different superscripts differ significantly $(P<0.05)$.

${ }^{1} \mathrm{DRM}=$ dried manure. 
Table 3. Effect of environment, water flow (on vs. off) through the heat exchangers, and bedding type on mean 24-h core body temperature (CBT), feed intake, milk yield, and resting time

\begin{tabular}{|c|c|c|c|c|c|}
\hline Item & Bed treatment $^{1}$ & \multicolumn{3}{|c|}{ Measurement } & $\begin{array}{c}\text { Resting time } \\
\mathrm{h} / \mathrm{d}\end{array}$ \\
\hline \multicolumn{6}{|l|}{ Climate } \\
\hline \multirow[t]{3}{*}{ Hot and dry } & Sand and water on & $38.77^{\mathrm{a}}$ & $41.46^{\mathrm{a}}$ & $29.74^{\mathrm{a}}$ & 9.90 \\
\hline & Sand and water off & $38.87^{\mathrm{b}}$ & $40.87^{\mathrm{a}}$ & $29.61^{\mathrm{a}}$ & 10.10 \\
\hline & DRM and water on & $39.05^{\mathrm{c}}$ & $38.48^{\mathrm{b}}$ & $27.55^{\mathrm{b}}$ & 8.94 \\
\hline \multirow{3}{*}{ Thermo neutral } & Sand and water off & $38.25^{\mathrm{a}}$ & $43.65^{\mathrm{ab}}$ & $30.67^{\mathrm{ab}}$ & $12.63^{\mathrm{a}}$ \\
\hline & DRM and water on & $38.38^{\mathrm{c}}$ & $41.35^{\mathrm{b}}$ & $29.80^{\mathrm{b}}$ & $10.64^{\mathrm{b}}$ \\
\hline & DRM and water off & $38.44^{\mathrm{d}}$ & $41.97^{\mathrm{b}}$ & $30.55^{\mathrm{ab}}$ & $11.65^{\mathrm{ab}}$ \\
\hline \multirow[t]{4}{*}{ Hot and humid } & Sand and water on & $38.64^{\mathrm{a}}$ & $43.18^{\mathrm{a}}$ & $31.04^{\mathrm{a}}$ & $10.69^{\mathrm{a}}$ \\
\hline & Sand and water off & $38.73^{\mathrm{b}}$ & $42.29^{\mathrm{ab}}$ & $29.62^{\mathrm{b}}$ & $10.58^{\mathrm{a}}$ \\
\hline & DRM and water on & $38.88^{\mathrm{c}}$ & $40.22^{\mathrm{bc}}$ & $28.86^{\mathrm{b}}$ & $9.16^{\mathrm{b}}$ \\
\hline & DRM and water off & $39.06^{\mathrm{d}}$ & $39.34^{\mathrm{c}}$ & $29.36^{\mathrm{b}}$ & $8.92^{\mathrm{b}}$ \\
\hline
\end{tabular}

$\overline{\mathrm{a}-\mathrm{d}}$ Means within each climate with different superscripts differ significantly $(P<0.05)$.

${ }^{1} \mathrm{DRM}=$ dried manure.

ments $\left(38.70\right.$ and $38.38^{\circ} \mathrm{C}$ for hot and dry, and hot and humid, respectively, $P<0.05$, Table 4 ).

Mean skin temperature and mean respiration rates are presented in Table 4. Cows under the treatment with sand and water on had lower skin temperatures in hot and dry $\left(36.77^{\circ} \mathrm{C}\right)$, thermo neutral $\left(28.7^{\circ} \mathrm{C}\right)$, and hot and humid $\left(34.1^{\circ} \mathrm{C}\right)$ environments $(P<0.05$, Table $4)$. Respiration rates were reduced with the treatment with sand and water on compared with other bed treatments in heat-stress climates (81.3 and 71.0 breaths/ min for hot and dry, and hot and humid, respectively). A difference was also observed between treatments with DRM and water on, and DRM and water off in thermo neutral (34.9 and 38.3 breaths/min, respectively) and hot and humid (80.6 and 86.6 breaths/min, respectively) environments $(P<0.05$, Table 4$)$.

Feed intake numerically increased in the cows during treatment with sand and water on (Table 3) in all climates. However, the cows lying on DRM-treatment beds ingested less feed compared with the other treatments $(P<0.05$, Table 3$)$. High moisture levels during treatment with DRM and water on may explain the difference in the feed intake.

A numerical increase in milk production was observed during treatment with sand and water on (Table 3) in all climates $(24.72,26.4,26.2 \mathrm{~kg} / \mathrm{d}$ for hot and dry, thermo neutral, and hot and humid, respectively). A significant decrease in milk production was observed

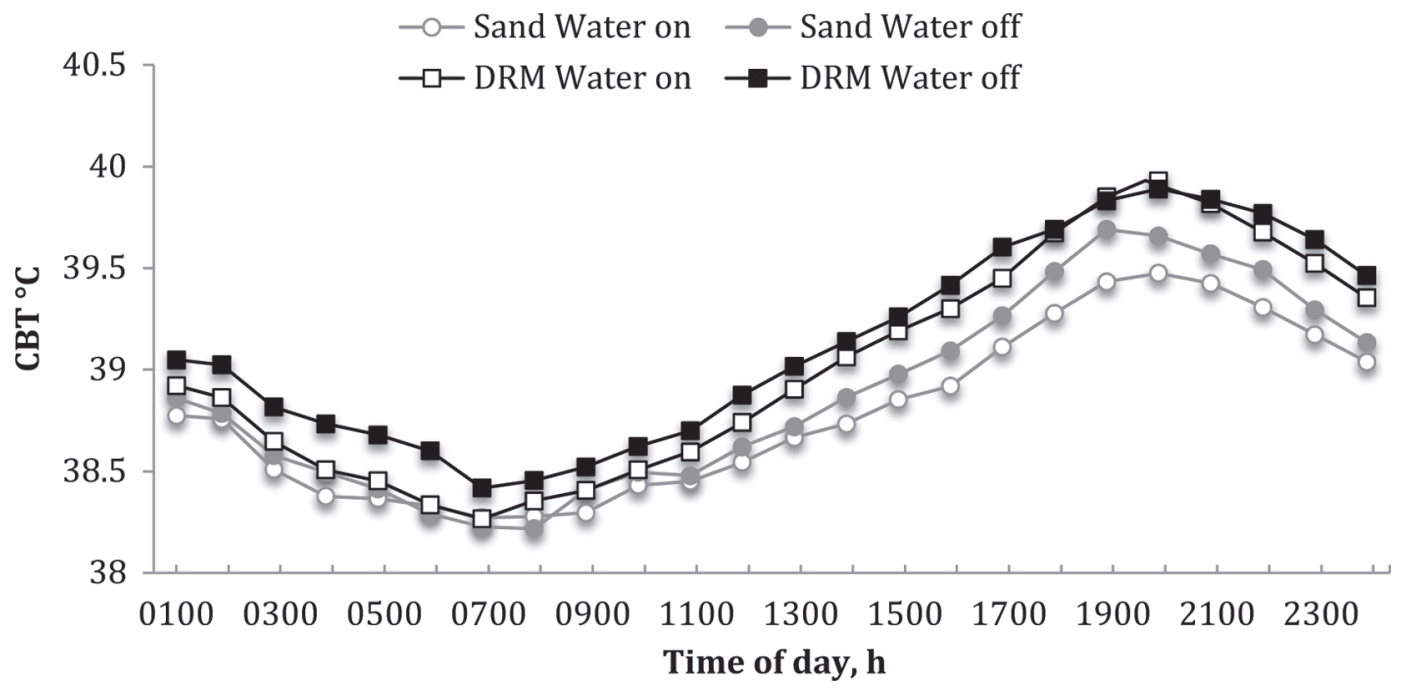

Figure 8. Effect of bedding type on circadian core body temperature (CBT) pattern in a hot and dry environment. DRM $=$ dried manure. Treatment-by-time interaction: $P<0.0001 ; \mathrm{SEM}=0.02$. 


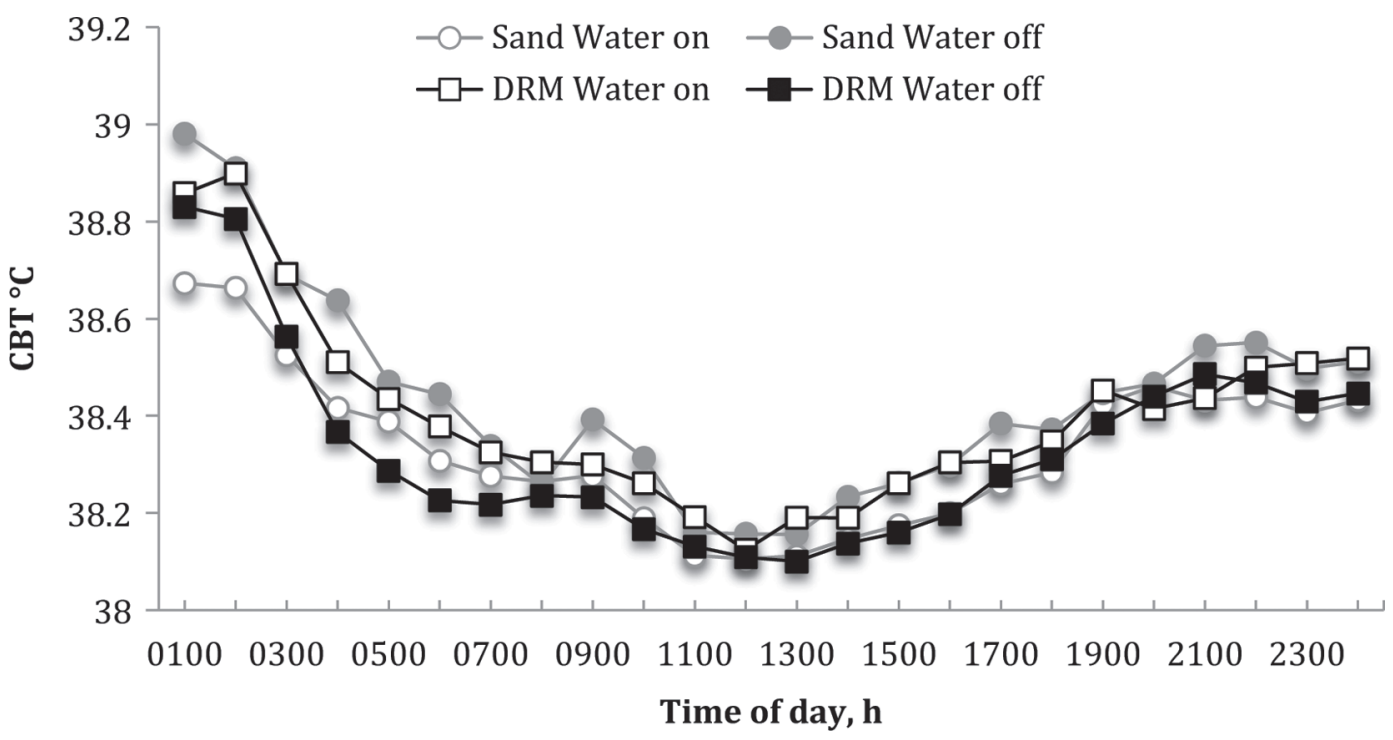

Figure 9. Effect of bedding type on circadian core body temperature (CBT) pattern in thermo-neutral environment. DRM $=$ dried manure. Treatment-by-time interaction: $P<0.0001 ; \mathrm{SEM}=0.02$.

during treatment with DRM and water on $(P<0.05$, Table 3); this difference may be explained by the reduction in the feed intake of this group (Table 3).

The milk yield and milk concentration during this trial are shown in Tables 5 and 6 , respectively. Whereas treatment with sand and water on showed an increase in milk fat, milk protein, and lactose production in hot and dry, and hot and humid environments $(P<0.05$, Table 5), no difference was observed between bed treatments in the concentration of milk fat and milk protein in all the climates. Lactose production was not affected by the use of heat exchangers; however, a difference in milk lactose production was observed between sand and DRM $(P<0.05$, Table 5$)$. The treatment with sand and water off showed higher concentration of milk lactose in all the environments $(P<0.05$, Table 6$)$. No difference was observed between bed treatments for milk-component production in the thermo-neutral environment. No differences were observed in the analysis of SCC in samples taken from cow milk during all bed treatments in all the different climates.

Resting time during this experiment is detailed in Table 3. We did not detect an increase in resting time during bed treatments with the water on. However,

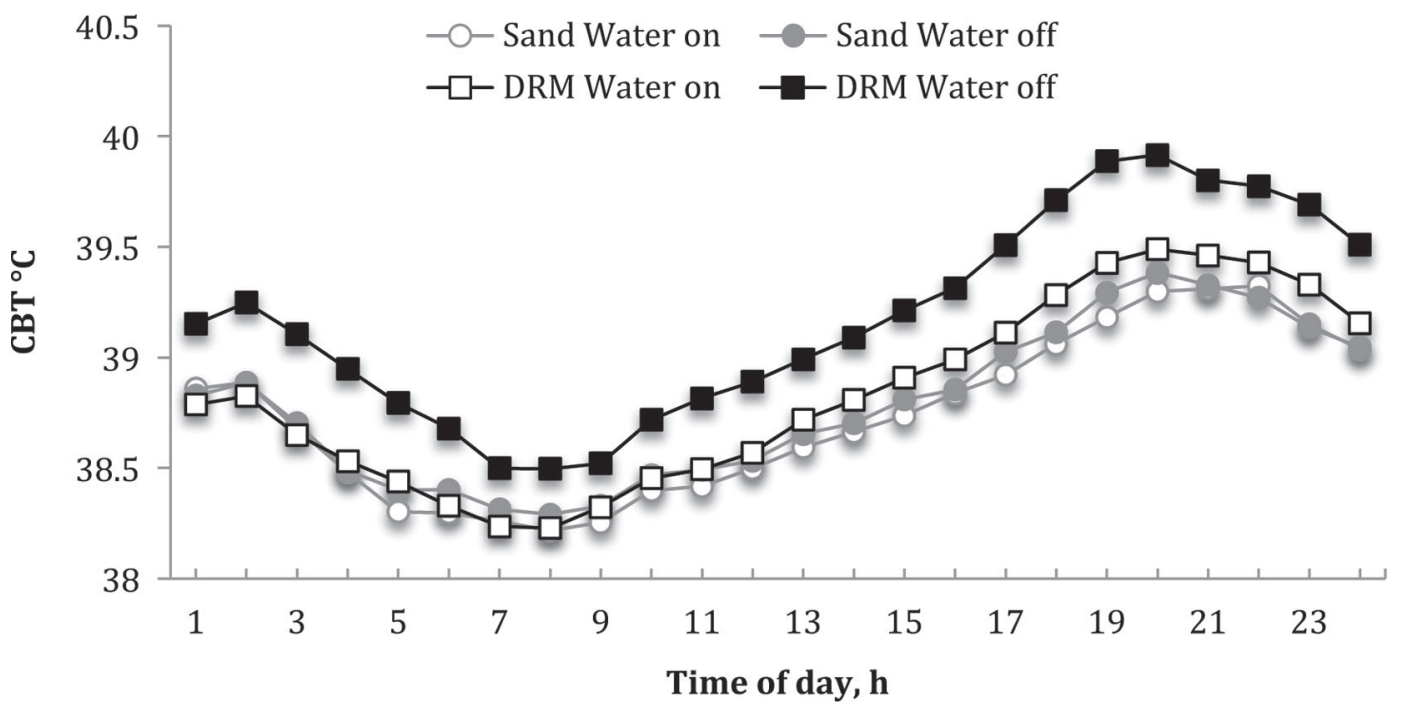

Figure 10. Effect of bedding type on circadian core body temperature (CBT) pattern in hot and humid environment. DRM $=$ dried manure. Treatment-by-time interaction: $P<0.0001 ; \mathrm{SEM}=0.02$. 
Table 4. Effect of environment and bedding on skin and rectal temperature and respiration rate (RR) in lactating Holstein cows

\begin{tabular}{|c|c|c|c|c|}
\hline Item & Bed treatment ${ }^{1}$ & \multicolumn{3}{|c|}{ Measurement } \\
\hline \multirow{3}{*}{$\begin{array}{l}\text { Climate } \\
\text { Hot and dry }\end{array}$} & Sand and water on & $81.3^{\mathrm{a}}$ & $36.6^{\mathrm{a}}$ & $38.70^{\mathrm{a}}$ \\
\hline & Sand and water off & $84.4^{\mathrm{ab}}$ & $37.2^{\mathrm{b}}$ & $38.85^{\mathrm{b}}$ \\
\hline & DRM and water on & $87.5^{\mathrm{b}}$ & $37.5^{\mathrm{c}}$ & $38.99^{\mathrm{c}}$ \\
\hline \multirow{3}{*}{ Thermo neutral } & Sand and water off & $30.2^{\mathrm{a}}$ & $28.8^{\mathrm{b}}$ & $37.90^{\mathrm{a}}$ \\
\hline & DRM and water on & $34.9^{\mathrm{b}}$ & $29.1^{\mathrm{c}}$ & $37.97^{\mathrm{a}}$ \\
\hline & DRM and water off & $38.3^{\mathrm{b}}$ & $29.2^{\mathrm{c}}$ & $37.95^{\mathrm{a}}$ \\
\hline \multirow[t]{4}{*}{ Hot and humid } & Sand and water on & $71.0^{\mathrm{a}}$ & $34.1^{\mathrm{a}}$ & $38.38^{\mathrm{a}}$ \\
\hline & Sand and water off & $73.7^{\mathrm{a}}$ & $34.5^{\mathrm{b}}$ & $38.51^{\mathrm{b}}$ \\
\hline & DRM and water on & $80.6^{\mathrm{b}}$ & $34.6^{\mathrm{b}}$ & $38.57^{\mathrm{b}}$ \\
\hline & DRM and water off & $83.6^{\mathrm{b}}$ & $34.4^{\mathrm{ab}}$ & $38.71^{\mathrm{c}}$ \\
\hline
\end{tabular}

${ }^{\mathrm{a}-\mathrm{c}}$ Means within each climate with different superscripts differ significantly $(P<0.05)$.

${ }^{1} \mathrm{DRM}=$ dried manure.

cows spent more time lying down when sand was used as the bedding material in all the different climates $(P<0.05$, Table 3$)$. Cows also decreased their lying time by $2 \mathrm{~h}$ during heat stress-inducing environments as compared with thermo-neutral conditions $(P<0.05$, Table 3).

The amount of heat flowing from the cows to their respective bed treatments when cows were lying down in their respective bed is presented in Table 2. Heat flow significantly increased when the heat exchangers were on under the respective bed materials $(P<0.05$, Table 2). Sand and water on produced the highest heat flow compared with the other treatments in all climates $\left(26.74,22.44\right.$, and $28.63 \mathrm{~W} / \mathrm{m}^{2}$ for hot and dry, thermo neutral, and hot and humid, respectively).
Moisture sensors placed in the beds stopped reading data because of saturation, and so that data collected during the study could not be used. However, at the end of the study, soil samples were taken and analyzed for moisture content at 3 different depths $(0,13$, and $25 \mathrm{~cm}$ below the bed surface). The moisture content of each bed treatment is shown in Figure 11. The beds with DRM and water on had the highest moisture content in the 3 layers from which samples were taken.

Differences between the supply and the return water temperatures are shown in Figure 12. The mean temperature differences between the supply and return for the different climates were $1.65^{\circ} \mathrm{C}$ for hot and dry, $1.25^{\circ} \mathrm{C}$ for thermo neutral, and $1.66^{\circ} \mathrm{C}$ for hot and humid $(P<0.01$, Figure 12).

Table 5. Effect of environment and bedding on milk composition of Holstein cows

\begin{tabular}{llccc}
\hline & & \multicolumn{3}{c}{ Measurement } \\
\cline { 3 - 4 } Item & Bed treatment ${ }^{1}$ & $\begin{array}{c}\text { Milk protein, } \\
\mathrm{kg} / \mathrm{d}\end{array}$ & $\begin{array}{c}\text { Milk fat, } \\
\mathrm{kg} / \mathrm{d}\end{array}$ & $\begin{array}{c}\text { Milk lactose, } \\
\mathrm{kg} / \mathrm{d}\end{array}$ \\
\hline Climate & & & \\
Hot and dry & & $0.76^{\mathrm{a}}$ & $0.88^{\mathrm{ab}}$ & $1.12^{\mathrm{a}}$ \\
& Sand and water on & $0.75^{\mathrm{ab}}$ & $0.98^{\mathrm{a}}$ & $1.11^{\mathrm{a}}$ \\
& Sand and water off & $0.70^{\mathrm{b}}$ & $0.84^{\mathrm{b}}$ & $1.03^{\mathrm{b}}$ \\
Thermo neutral & DRM and water on & $0.74^{\mathrm{ab}}$ & $0.90^{\mathrm{ab}}$ & $1.10^{\mathrm{ab}}$ \\
& DRM and water off & 0.80 & 0.87 & 1.15 \\
& Sand and water on & 0.80 & 0.91 & 1.16 \\
Hot and humid & Sand and water off & 0.77 & 0.86 & 1.12 \\
& DRM and water on & 0.77 & 0.90 & 1.15 \\
& DRM and water off & $0.81^{\mathrm{a}}$ & $0.92^{\mathrm{a}}$ & $1.19^{\mathrm{a}}$ \\
SEM & Sand and water on & $0.75^{\mathrm{b}}$ & $0.80^{\mathrm{b}}$ & $1.07^{\mathrm{b}}$ \\
& Sand and water off & $0.74^{\mathrm{b}}$ & $0.89^{\mathrm{ab}}$ & $1.09^{\mathrm{b}}$ \\
& DRM and water on & $0.75^{\mathrm{b}}$ & $0.88^{\mathrm{ab}}$ & 0.06 \\
\hline
\end{tabular}

$\overline{\mathrm{a}, \mathrm{b}}$ Means within each climate with different superscripts differ significantly $(P<0.05)$.

${ }^{1} \mathrm{DRM}=$ dried manure. 
Table 6. Percentages of milk composition of cows in 4 types of bed treatments and 3 different climates

\begin{tabular}{|c|c|c|c|c|}
\hline \multirow[b]{2}{*}{ Item } & \multirow[b]{2}{*}{ Bed treatment ${ }^{1}$} & \multicolumn{3}{|c|}{ Measurement } \\
\hline & & Milk protein, & $\begin{array}{c}\text { Milk fat, } \\
\%\end{array}$ & $\begin{array}{c}\text { Milk lactose, } \\
\%\end{array}$ \\
\hline \multicolumn{5}{|l|}{ Climate } \\
\hline \multirow[t]{4}{*}{ Hot and dry } & Sand and water on & 3.17 & 3.67 & $4.62^{\mathrm{ab}}$ \\
\hline & Sand and water off & 3.16 & 3.78 & $4.71^{\mathrm{b}}$ \\
\hline & DRM and water on & 3.12 & 3.96 & $4.57^{\mathrm{a}}$ \\
\hline & DRM and water off & 3.03 & 3.58 & $4.62^{\mathrm{ab}}$ \\
\hline \multirow[t]{4}{*}{ Thermo neutral } & Sand and water on & 3.19 & 3.35 & $4.63^{\mathrm{ab}}$ \\
\hline & Sand and water off & 3.18 & 3.58 & $4.74^{\mathrm{a}}$ \\
\hline & DRM and water on & 3.16 & 3.67 & $4.54^{\mathrm{b}}$ \\
\hline & DRM and water off & 3.05 & 3.51 & $4.58^{\mathrm{ab}}$ \\
\hline \multirow[t]{4}{*}{ Hot and humid } & Sand and water on & 3.17 & 3.59 & $4.63^{\mathrm{ab}}$ \\
\hline & Sand and water off & 3.13 & 3.47 & $4.76^{\mathrm{a}}$ \\
\hline & DRM and water on & 3.17 & 3.89 & $4.54^{\mathrm{b}}$ \\
\hline & DRM and water off & 3.14 & 3.65 & $4.54^{\mathrm{b}}$ \\
\hline SEM & & 0.07 & 0.2 & 0.06 \\
\hline
\end{tabular}

a,b Means within each climate with different superscripts differ significantly $(P<0.05)$.

${ }^{1} \mathrm{DRM}=$ dried manure.

\section{DISCUSSION}

The negative effects that high ambient conditions have on the milk yield and feed consumption of dairy cows have been reported at THI as low as 68 (Zimbelman et al., 2009). In this trial, THI measurements for hot and dry, and hot and humid climates ranged between 67 and 86 and were above a THI of 68 for $21 \mathrm{~h}$ per day, a level that represents mild to moderate stress (Zimbelman et al., 2009). The THI of the thermo-neutral environment ranged between 56 and 73 , and THI was above 68 for $2 \mathrm{~h}$ per day. The physiological indicators used in this experiment to identify

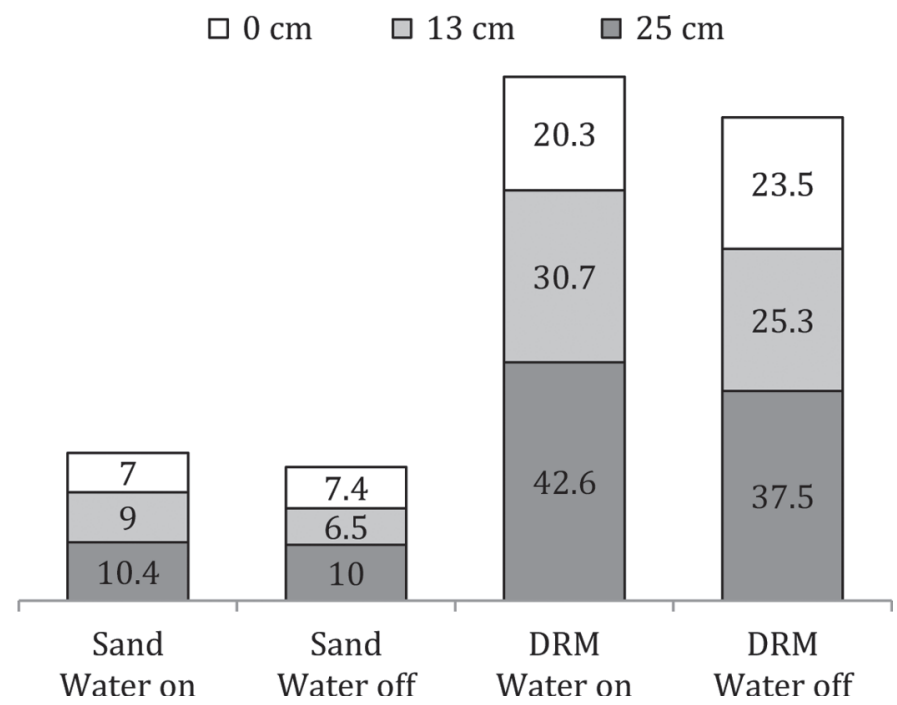

Figure 11. Percentage of moisture content of 4 types of bed treatments at 3 different depths (0, 13, and $25 \mathrm{~cm}$ below the surface). DRM $=$ dried manure heat stress (respiration rate, rectal temperature, water intake) indicated the animals were above the threshold for heat stress. For dairy cows under thermo-neutral conditions, core body temperature ranged from 38 to $39.3^{\circ} \mathrm{C}$, with an average of $38.6^{\circ} \mathrm{C}$ (Dukes, 1947). Zimbelman et al. (2010) reported an average respiration rate of 38 breaths $/ \mathrm{min}$ and a skin temperature of $29.9^{\circ} \mathrm{C}$ during thermo-neutral conditions. Berman et al. (1985) reported that the stress threshold for respiration rate was 60 breaths/min, which is half maximal. These same investigators reported that the heat-stress threshold for skin temperature was $35^{\circ} \mathrm{C}$ (Berman et al., 1985).

Our results indicated that bed temperatures at $10 \mathrm{~cm}$ above the heat exchanger and at the surface of the beds

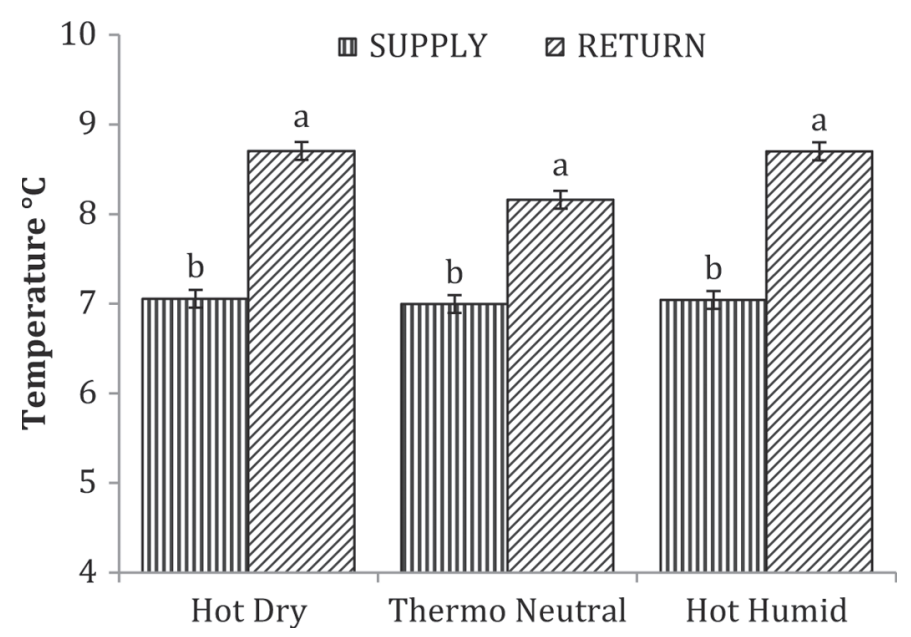

Figure 12. Mean temperature of water returning from the heat exchangers in 3 different climates. ${ }^{\mathrm{a}, \mathrm{b}} \mathrm{Bed}$ treatments with different letters are significantly different $(P<0.05)$ in their respective climate. 
increased during high ambient temperature conditions. This suggests an exchange of temperature between the bed surface material and the environment.

Based on the results shown in this paper, it can be assumed that heat exchangers can be used as a heatabatement method in hot and dry, and hot and humid environments. This is especially important in humid environments in which cows depend on respiratory evaporation to reduce their metabolic heat.

Even though a significant difference in the CBT was observed between the DRM and water on, and DRM and water off treatments, other physiological measurements (skin temperature, respiration rate, milk yield, and feed intake) did not improve when the heat exchanger was on. These mixed results might be the result of the low heat flow occurring between the cow and this type of bed treatment, and the higher capacity of DRM to absorb and retain water (Stowell and Inglis, 2000) because water has a high thermal conductivity and volumetric heat capacity and will retain heat longer than sand. Schmidt-Nielsen (1964) reported that conductive heat exchange is compromised when gases or liquids are involved in the media. Fregonesi et al. (2007) documented a difference in lying time of $5 \mathrm{~h} / \mathrm{d}$ when dry bedding material was compared with wet bedding. The relatively high moisture content in the DRM beds also created an increase in mud formation; the negative effects that mud has on dairy cows have been reported previously (Kirk, 2008). However, this particular experiment was conducted in a tie-stall facility, and thus a relatively high amount of urine and feces was deposited on the bedding material. At a commercial dairy farm, it is more common for cows to defecate and urinate in the alleys and not in their beds. More research analyzing the use of heat exchangers in conjunction with DRM bedding material is needed to further evaluate the heat flux occurring between this type of bedding material and the animal.

It should be noted that Bastian et al. (2003) reported higher heat flux values than the ones recorded during this experiment; however, Bastian used water-filled mattresses that were in direct contact with the hair and skin of the cows. Also, Mondaca et al. (2013) were able to demonstrate a direct relationship between effectiveness of a heat exchanger and the amount of the bedding material between the exchanger and the cow. Future research should focus on finding ways to decrease the depth of the bedding material (and thereby increase the heat loss of the cow) without jeopardizing cow comfort and safety as well as while protecting the heat-exchange equipment.

Of the bed treatments evaluated in this experiment, sand and water on was superior to DRM in its ability to counteract heat stress through conduction. These results agree with the thermal conductivity of sand versus that of DRM $\left[0.33\right.$ and $0.108 \mathrm{~W} /\left(\mathrm{m} \cdot \mathrm{C}^{\circ}\right)$, respectively] (Monsenin, 1980; Bohnhoff and Converse, 1987).

In agreement with the model developed by Mondaca et al. (2013), it was observed that the use of heat exchangers at $25 \mathrm{~cm}$ does decrease the CBT of dairy cows; however, the conditions used in this experiment differ to the ones used in the model (ambient temperature, bedding type, CBT of cows, and heat-exchange temperature).

These results support the need for further work to increase the efficiency of passive conductive cooling used to alleviate heat stress in lactating dairy cows. Further research should also seek to identify the best way to operate the heat exchangers in commercial dairy farms. Some other concerns should also be addressed: the effects of heat exchangers deployed in free stalls that rely on DRM for bedding, the depth at which the heat exchanger should be placed to maximize its cooling capacity, the additional cooling systems that might be required to maintain a minimal level of heat stress during peak stress seasons, and the efficacy of using antifreeze additives to lower the temperature of the circulating water.

Nowadays it is more common to see how dairy producers are struggling with the reduction of natural resources available for agriculture. It is the right time to start looking for more efficient ways to optimize the dairy industry and reduce the usage of scarce resources. Conductive cooling showed to be a good start in this process; however, its efficiency will always be linked to the gradient difference between the skin of the animal and the surface in contact. Even though the use of water chillers is a viable alternative to reduce the water temperature, water chillers consume energy, which is considered as a main production cost. Some studies (Scully, 2014) are looking at the use of reclaimed heat from anaerobic digesters to run water chillers and at the same time take advantage of available energy in the farm to cool down cows. Other alternatives such as passively cooled barns and sustainable cooling systems should be investigated in the future to have a much bigger reduction in the use of natural resources.

\section{ACKNOWLEDGMENTS}

This project was supported financially by GEA Farm Technologies. The authors thank all the undergraduates, graduate students, and staff members at the University of Arizona who assisted in this experiment. The authors of this paper thank John F. Smith for his leadership and dedication to the dairy industry. His 
work and unconditional support made him an excellent mentor and colleague, but above all, his kind and generous heart made him a great person and friend.

\section{REFERENCES}

Bastian, K. R., K. G. Gebremedhin, and N. R. Scott. 2003. A finite difference model to determine conduction heat loss to a waterfilled mattress for dairy cows. Trans. ASAE 46.3:773-780.

Berman, A., Y. Folman, M. Kaim, M. Mamen, Z. Herz, D. Wolfenson, A. Arieli, and Y. Graber. 1985. Upper critical temperatures and forced ventilation effects for high-yielding dairy cows in a subtropical climate. J. Dairy Sci. 68:1488-1495.

Bohnhoff, D. R., and J. C. Converse. 1987. Engineering properties of separated manure solids. Biol. Wastes 19:91-106.

Bruer, J. C., and W. T. Steele. 2011. Thermal Conductive Cooling Method and System for Livestock Farm Operations. Conco Technology Inc., assignee. US Pat. No. US 2011/0283952 A1.

Collier, R. J., G. E. Dahl, and M. J. VanBaale. 2006. Major advances associated with environmental effects on dairy cattle. J. Dairy Sci. 89:1244-1253.

Cook, N. B., T. B. Bennett, and K. V. Nordlund. 2004. Effect of free stall surface on daily activity patterns in dairy cows with relevance to lameness prevalence. J. Dairy Sci. 87:2912-2922.

Cummins, K. 1998. Bedding plays role in heat abatement. Dairy Herd Manag. 35:20.

Dukes, H. H. 1947. The Physiology of Domestic Animals. 6th ed. Comstock Publishing Company Inc., Ithaca, NY.

Esmay, M. L. 1969. Principles of Animal Environment. The AVI Publishing Company Inc., Westport, CT.

Fregonesi, J. A., D. M. Veira, M. A. G. von Keyserlingk, and D. M. Weary. 2007. Effects of bedding quality on lying behavior of dairy cows. J. Dairy Sci. 90:5468-5472.

Harner, J. P., M. J. Brouk, J. Potts, B. Bradford, and J. F. Smith. 2013. Scientific data for developing water budgets on a dairy. Pages 91-103 in Proc. West. Dairy Manag. Conf., Reno, NV. Western Dairy Management Conference, Manhattan, KS.

Husfeldt, A. W., M. I. Endres, J. A. Salfer, and K. A. Janni. 2012. Management and characteristics of recycled manure solids used for bedding in Midwest freestall dairy herds. J. Dairy Sci. 95:21952203 .
Kadzere, C. T., M. R. Murphy, N. Silanikove, and E. Maltz. 2002. Heat stress in lactating dairy cows: A review. Livest. Prod. Sci. 77:59-91.

Kirk, J. H. 2008. The effects of mud on your dairy cows. Prog. Dairyman 508:34.

Mondaca, M., F. Rojano, C. Y. Choi, and K. Gebremedhin. 2013. Conjugate heat and mass transfer model to evaluate the efficiency of conductive cooling for dairy cattle. Trans. ASABE 56:1471-1482.

Monsenin, N. 1980. Thermal Properties of Foods and Other Agricultural Materials. Gordon and Breach, Science Publishers Inc., New York, NY.

Radoń, J., W. Bieda, J. Lendelová, and Š. Pogran. 2014. Computational model of heat exchange between dairy cow and bedding. Comput. Electron. Agric. 107:29-37.

Schmidt-Nielsen, K. 1964. Desert Animals: Physiological Problems of Heat and Water. The Clarendon Press, Oxford, UK.

Scully, T. 2014. Multi-faceted study captures heat, cools cows. Prog. Dairyman 28:63-64.

St-Pierre, N. R., B. Cobanov, and G. Schnitkey. 2003. Economic losses from heat stress by US livestock industries. J. Dairy Sci. 86(Suppl.):E52-E77.

Stowell, R. R., and S. Inglis. 2000. Sand for bedding. Pages 226-234 in Dairy Housing and Equipment Systems: Managing and Planning for Profitability. Natural Resource, Agriculture, and Engineering Service, Camp Hill, PA.

USDA. 2013. Milk Production. Dec. 2012. USDA, National Agricultural Statistics Service. Accessed Jun. 5, 2013. http://www.usda. gov/nass/PUBS/TODAYRPT/mkpr1113.pdf.

van Gastelen, S., B. Westerlaan, D. J. Houwers, and F. J. C. M. van Eerdenburg. 2011. A study on cow comfort and risk for lameness and mastitis in relation to different types of bedding materials. J. Dairy Sci. 94:4878-4888.

Zimbelman, R. B., L. H. Baumgard, and R. J. Collier. 2010. Effects of encapsulated niacin on evaporative heat loss and body temperature in moderately heat-stressed lactating Holstein cows. J. Dairy Sci. 93:2387-2394.

Zimbelman, R. B., R. P. Rhoads, M. L. Rhoads, G. C. Duff, L. H. Baumgard, and R. J. Collier. 2009. A re-evaluation of the impact of temperature humidity index (THI) and black globe humidity index (BGHI) on milk production in high producing dairy cows. Pages 158-168 in Proc. Southwest Nutr. Manag. Conf., Tempe, AZ. University of Arizona, Tucson. 